\title{
PH.D.-AFHANDLING OM RABBI NAHMANS FORTÆLLINGER
}

Ved et offentligt forsvar for afhandlingen A Theology of Redemption - An Analysis of the Thirteen Tales in Rabbi Nahman of Bratslav's Sippurey Ma'asiyot, indleveret til bedømmelse ved Det Teologiske Fakultet, Aarhus Universitet, erhvervede Marianne Schleicher ph.d.-graden samme sted den 21. marts 2003. Bedømmelsesudvalget bestod af formand, lektor Hans J. Lundager Jensen (Århus), professor Rachel Elior, Hebrew University (Israel) samt professor Arnold J. Band, University of California (Los Angeles, USA). Nedenfor bringes en oversat og redigeret udgave af Marianne Schleichers indledning og resumé ved forsvaret fulgt af en redigeret udgave af Hans J. Lundager Jensens indlceg ved samme lejlighed.

Indledning og resumé ved Marianne Schleicher

Ph.d.-afhandlingen A Theology of Redemption - An Analysis of the Thirteen Tales in Rabbi Nahman of Bratslav's Sippurey Ma'asiyot er skrevet med det formål dels at bidrage til den løbende diskussion, der foregår inden for judaistikken om udlægningen af Rabbi Nahmans tretten fortællinger, dels at præsentere religionsvidenskaben for en systematisk redegørelse for en af de mest komplekse jødisk-mystiske teologier.

Rabbi Nahmans tretten fortællinger, der er kendt under titlen Sippurey Ma'asiyot, blev fortalt mellem 1806 og 1810 i Bratslav, Ukraine. ${ }^{1}$ Forud for mit ph.d.-projekt var status, at mange forskere havde udtalt sig om fortællingerne ud fra et kendskab til enkelte af fortællingerne og især ud fra et kendskab til Nahmans fascinerende og komplekse personlighed. Som oldebarn af hasidismens grundlægger, dvs. den jødisk mystiske retning, der fra 1750'erne revolutionerede østeuropæisk jødedom, voksede Nahman op med et stort forventningspres, der ikke blev mindre af den maniodepressivitet, der prægede hans sind (Green 1992 (1979), 24-41). Forventningspres og maniodepressivitet er blevet fremhævet som medvirkende årsager til hans messiasprætentioner, hvor han frem til 1806 hævdede både at være Mashiah ben Yosef og Mashiah ben David. Mashiah ben Yosef er i jødedommen den, der skal bane vej for den egentlige Messias, som netop betegnes Mashiah ben David. Efter adskillige traumatiske begivenheder i 1806 indså han dog, at han næppe var udvalgt til at være selve forløseren, men at Gud fortsat ønskede, at han skulle bane vej for forløsningen. Nahman holdt således fast i opfattelsen af sig selv som Mashiah ben Yosef. En personlighed som Nahmans er selvfølgelig fascinerende, men det stødte mine akademiske idealer om grundighed og belæg, at man kunne

\footnotetext{
${ }^{1}$ Sippurey Ma'asiyot blev første gang udgivet 1815 på hebræisk og jiddisch. Den tosprogede version ligger til grund for den oversættelse til engelsk, som jeg har foretaget som led i min nærlæsning. De to andre eksisterende oversættelser til engelsk er Arnold J. Bands og Aryeh Kaplans.
} 
udtale sig om det samlede tekstkorpus, bl.a. som projektioner af Nahmans komplekse sind, når ingen nogensinde havde ulejliget sig med at analysere samtlige tretten fortællinger.

Sippurey Ma'asiyot kan betegnes som gådefulde fortællinger, hvor det gådefulde indtryk kan forklares ved, at fortællingernes narrative forløb virker usammenhængende og uforståelige, medmindre man kan trække på et kendskab til traditionelt og mystisk jødisk billedsprog. Netop fortællingernes gådefulde karakter har opdelt tilhørere og læsere i dem, der har taget den manglende sammenhæng for pålydende, og i dem, der har opfanget det gådefulde som en invitation til at finde en indgang til fortællingernes betydningslag.

Nahmans tilhængere, kendt som 'bratslaverne', forventede og forventer, at fortællingerne rummer henvisninger til et teologisk budskab. De opfatter fortællingernes mange beskrivelser som allegorier og 'oversætter' allegorierne direkte i overensstemmelse med den forventning, som de har til Nahman om, at han skulle være en såkaldt Zaddik haDor. Zaddik haDor betyder 'generationens retfærdige' og refererer til den forestilling, at der i enhver generation fremstår et menneske af en sådan retfærdig karakter, at han kan bane vej for Messias, hvis det lykkes ham at bringe sin samtid til at angre og sone dens synder.

De første akademikere, der udlagde fortællingerne, tæller bl.a. Martin Buber og Joseph Weiss. Buber og Weiss var begge ude i et eksistentialistisk ærinde. Buber lod sig inspirere til sin Jeg-Du-filosofi af Nahmans krav til sine tilhængere om en times daglig dialog med Gud på dus og modersmål for at sikre det personlige Gudsforhold (Buber 1906; 1923). Med Søren Kierkegaards begreb ‘den paradokse tro’ som analytisk redskab og under inddragelse af de tidlige, historisk-kritiske analysemetoder, redegjorde Weiss for, hvordan Nahmans teologi adskilte sig fra den monistiske teologi, som typisk forbindes med hasidismen, og som benævnes 'Contemplative Mysticism'. Til forskel fra denne kontemplative mystik mente Weiss, at Nahmans teologi burde betegnes 'Hasidism of Faith', fordi tro og ikke systematisk kontemplation var det eneste middel for mennesket til at bygge bro over den eksistentielle kløft, der adskilte Gud og mennesket (Weiss 1997 (1953)). Det var her et krav til potentielle tilhængere, at de skulle tilsidesætte deres eget intellekt og erstatte det med fuldstændig tillid til Gud såvel som til Nahman, fordi Nahman som Zaddik haDor, altså den særligt, retfærdige leder, havde indsigt $\mathrm{i}$ det guddommeliges ontologiske transcendens og dermed besad evnen til direkte at kunne følge og formidle Guds tankegang. I kraft af sin indsigt besad Nahman evnen til at lede sine tilhængere over kløften. Med henvisning til Nahmans homiletiske værker argumenterede Weiss derfor for, at alt, hvad Nahman sagde og skrev, tog sit udgangspunkt i Nahmans opfattelse af sig selv som Zaddik haDor. Uden først at analysere fortællingerne hævdede han, at de formidlede Nahmans selvopfattelse (Weiss 1997 (1969)), 254; Weiss 1974, 152)

Joseph Dan gik et skridt videre i forhold til Weiss' opfattelse af fortællingerne som selvbiografiske, da han i 1975 analyserede fire af dem. Dan argumenterede for, at det ikke var muligt at afsløre noget didaktisk budskab - hverken teologisk eller etisk - i 
Nahmans fortællinger. Havde Nahman, der var kendt som en fremragende didaktiker, villet kommunikere et budskab, ville han ikke have undladt at udstyre fortællingerne med en sammenhængende mening. Man skulle derfor, ifølge Dan, opfatte fortællingerne som litterære, men samtidigt personlige udtryk for Nahmans martrede sjæl og som hans forsøg på at forlige sig med sin messianske prætention om at forløse verden qua sin identitet som Zaddik haDor (Dan 1975, 143).

De fleste akademiske udgivelser om fortællingerne har siden argumenteret for, at fortællingerne har både et selvbiografisk og et didaktisk indhold. De to kendteste bidrag, der afspejler denne mediering af tilgange, er Arnold J. Bands og Arthur Greens. Green skrev en imponerende biografi i 1979, hvor han læser fire ud af tretten fortællinger biografisk, omend han dog åbner sig for fortællingernes didaktiske aspekter. Band udgav i 1978 den første oversættelse af samtlige tretten fortællinger med en 2- til 4siders kommentar til hver fortælling, som naturligvis ikke kan formidle en dybtgående analyse. Det er først i "The Function of the Enigmatic in Two Hasidic Tales" fra 1982, at Band i detalje argumenterer for en kommunikativ funktion ved det gådefulde i Nahmans sjette fortælling, hvormed der åbnes for en ny tilgang til fortællingerne. Den tilsyneladende manglende sammenhæng i denne ifølge Band repræsentative fortælling fungerer som en invitation til at træde ind i det fantastiskes univers, hvor den umiddelbare virkelighed suspenderes for i stedet at tilbyde en anderledes form for viden og sansning (Band 1982, 193 og 198f).

Det var dog stadig påfaldende, hvor mange der talte om fortællingernes generelle karakteristika, og nogle endda om deres manglende sammenhæng, uden at nogen nogensinde havde gennemført en nærlæsning af alle tretten fortællinger med argumenter for deres læsninger. For at gøre det muligt for fremtidens forskere og mig selv at tale om fortællingerne på et overordnet plan, fandt jeg det derfor nødvendigt at gennemføre den første nærlæsning af samtlige tretten fortællinger; at oversætte dem fra den tosprogede originaludgave på hebræisk og jiddisch for at sikre berøringen med hvert enkelt ord; og at præsentere argumenterne for min analyse af samtlige fortællinger.

Jeg delte Bands opfattelse af, at fortællingernes gådefulde karakter skulle opfattes som en invitation til at reflektere over fortællingerne. Det var imidlertid på sin plads at præcisere, hvad det overhovedet var, der konstituerede samtlige fortællingers gådefulde karakter, inden man begyndte at lede efter en mening bag det gådefulde.

Det gådefulde fandt jeg i det fantastiske ved fortællingerne, hvor fortælleforløb og angivelser af tid og sted sprængte rammerne for det forklarlige. Fortællingerne var - og er - fulde af helte og heltinder, skurke, djævle og dæmoner. Overnaturlige kræfter griber ind for at hjælpe de gode og straffe de onde. Det til trods nægter fortællingerne at afsløre en sammenhængende mening af sig selv, sådan som en eventyragtig fortælling burde gøre. Intet afsløres, hvis man blot retter sin opmærksomhed mod hver enkelt bestanddel i teksten, det være sig sætninger, ord eller tegn, og mod fortælleforløb og strukturer. Intet afsløres, hvis man blot kombinerer alt det umiddelbart observerede. Intet afsløres, hvis man forsøger at anvende en bestanddel til at forstå en anden. Uanset hvad man gør, vil fortællingernes indhold forblive utilgængeligt, med mindre man ind- 
ser, at disse bestanddele opnår mening gennem interaktion med deres kontekst, dvs. fortællingerne, og den historiske kontekst uden for fortællingerne, som de som billeder refererer til. En sådan interaktion er kendetegnende for billedsprog, og jeg valgte derfor at forstå disse bestanddele som billedsprog.

Den ukrainske hasidisme i begyndelsen af 1800-tallet udgjorde Nahmans historiske og religiøse kontekst. Fortællingerne portrætterede imidlertid figurer og værdier, der var kendt som hasidiske, på en til tider kritisk måde, hvilket fremkaldte det indtryk, at der herskede en spænding mellem fortællingerne og hasidismen. Alene begrebet Zaddik haDor er et begreb, hvis forløsningsimplikationer indikerer, at luriansk kabbalah, en tidligere mystisk retning, også kunne opfattes som en aktiveret kontekst. De narrative strukturer og de anvendte billeder vækkede desuden associationer til bibelsk og rabbinsk litteratur og først og fremmest til det kabbalistiske tekstkorpus Sefer haZohar. Disse eksterne kildetekster rummede strukturer og billeder, der forlenede fortællingerne med mening. Jeg valgte derfor at opfatte disse eksterne kildetekster som intertekster.

Spørgsmålet var imidlertid, hvordan jeg på adækvat vis kunne forholde mig til billedsproget og intertekstualiteten? Mit svar fandt jeg i Kirsten Nielsens definitioner af de informative og performative funktioner ved billedsprog og intertekster. Hendes definitioner tager udgangspunkt $i$, at billedsproget og intertekstualiteten tilbyder sig som indgange til et tekstmateriale, der inviterer tilhøreren/læseren til at deltage i en fortolkningshandling med det formål at udlede information af interaktionen mellem sagdel og billeddel, mellem tekst og intertekst. Denne invitation afspejler ifølge Kirsten Nielsen billedsprogets og intertekstualitetens natur som det at tilbyde udkast til en ny virkelighedsforståelse, at opfordre tilhøreren/læseren til at overtage denne virkelighedsforståelse og handle i overensstemmelse dermed (Nielsen 1989, 29 og 54-58; Nielsen 1998, 3336).

De tretten fortællinger nyder kanonisk status blandt bratslaverne pga. Nahmans overvejende påstand om, at han som den sidste Zaddik haDor havde indsigt i Guds ontologiske transcendens og dermed besad evnen til direkte at kunne følge og formidle Guds tankegang. Fordi en kanonisk eller hellig tekst opnår hellighed gennem påståede guddommelige eller guddommeligt autoriserede budskaber, og fordi der er konstante referencer til kanoniske og hellige tekster fra den jødisk-mystiske tradition, formodede jeg med argumenter hentet fra Boaz Huss og Lars Albinus, at fortællingerne kandiderede til at tilbyde adgang til guddommelig indsigt og mulighed for tilhøreren/læseren til at indgå i interaktion med det guddommelige (Huss 1998; Albinus 2000). Som en følge heraf tjente de intertekstuelle referencer til kanoniske og hellige tekster det formål at legitimere fortællingernes performative opfordring og at foreslå en reinterpretation af den religiøse tradition.

Med den formodning som afsæt for en nærlæsning signalerede jeg - $\mathrm{i}$ klar opposition til den selvbiografiske fløj - at jeg forventede, at fortællingerne havde et didaktisk indhold. Min forventning blev indfriet med en konstatering af fortællingernes informative og performative funktion, der kan opsummeres på følgende vis: Gennem de tretten fortællinger understreges det gang på gang i overensstemmelse med det lurianske para- 
digme, at den primordiale tidsalder, dvs. tiden forud for verdens skabelse, var kendetegnet ved, at alt var Gud og alt, der kunne opfattes, var Guds infinitet. Selv efter Guds beslutning om at skabe forblev og forbliver Gud det infinitte alting. Det var Guds vilje at skabe verden og alt i den. Som del af Guds skabelon for skabelsen skulle Israels folk forudbestemmes til en pagt med Gud, og Israels folk skulle sammen med Shekhinah, Guds tilstedeværelse i verden, administrere Guds skabelse. Dog havde Gud allerede i den primordiale tidsalder en forudanelse om, at noget ville gå galt, og at menneskehedens adfærd som et resultat ikke ville afspejle Guds vilje. Gud forudbestemte derfor ondskabens natur til i sidste ende at være selvdestruktiv som et middel til at overtale mennesket til ikke at vælge det onde.

Guds forudanelse var korrekt, og den primordiale katastrofe indtraf. Den indebar, at menneskets evne til at erkende blev begrænset til kun at kunne opfatte det finitte, dvs. alt, hvad der befinder sig inden for tid og rum. Mennesket kunne derfor ikke erkende Guds infinitte væsen. Mennesket kan ikke erkende, at Gud i Guds guddommelige infinitet er den eneste og absolutte autoritet, hvis bud bør erkendes som Guds forsøg på at rådgive mennesket i overensstemmelse med en infinit indsigt. I stedet vælger mennesket at have tiltro til sin egen tilsyneladende evne til at erkende. Fortællingerne informerer og advarer mod, hvordan tiltro til denne evne fører til en syndig adfærd. Syndig adfærd forværrer verdens tilstand, hvilket igen leder til ondskabens øgede indflydelse og forårsager en kontinuerlig forvrængning af skabelsen, der bringer lidelse til alle.

Den håbsformidlende information er, at da den primordiale katastrofe fandt sted, opstod kløften mellem Gud og skabelsen kun i den menneskelige bevidsthed. Set fra Guds perspektiv eksisterer der stadig et bindeled. Guddommelige gnister af Guds infinitte essens er til stede i alle dele af skabelsen, selvom de eksisterer som gnister, der er omkranset af ondskab. Alting er inde i Gud, og Gud er inde i alting. Af den grund argumenterer jeg mod Weiss' brug af Kierkegaards begreb om den paradokse tro, idet der ikke, hvad angår det ontologiske, er noget paradoks ved at afkræve mennesket en tro på Gud som infinit væsen, når mennesket rummer infiniteten inde i sig selv. Illusionen, som mennesket lever med, vil forsvinde den dag, hvor menneskets erkendelsesevne bliver restitueret. Man kan hævde, at Nahmans teologi i sidste ende vil afsløre sig som monistisk. ${ }^{2}$ Det eneste problem er blot, at den messianske forløsning er en forudsætning for at undslippe illusionen.

Fortællingernes teologi koncentrerer sig derfor om at forklare, hvordan mennesket kan forløses fra illusionen. På nuværende tidspunkt forhindrer de guddommelige gnisters indesluttethed bag ondskabens skaller mennesket $i$ at erkende behovet for forløsning og forstå den vejledning, som Gud har nedfældet i TaNaKh, dvs. den hebræiske bibel, som er for hånden. Menneskets forløsningsbehov kan imidlertid erkendes, hvis to forudsætninger er opfyldt: For det første må mennesket tillade, at de tretten fortællinger i Sippurey Ma'asiyot renser menneskets forestillingsevne. For det andet må mennesket lytte til den information, som er blevet tilgængelig gennem Nahmans adgang til den

\footnotetext{
2 Jeg går her imod Weiss 1997 (1953).
} 
transcendente sfære, og som er nedfældet i fortællingerne som en ny slags helligtekster, der rummer en guddommelig diskurs. ${ }^{3}$ Tager mennesket denne guddommelige diskurs til sig som et udkast til en ny virkelighedsforståelse, vil mennesket efterfølgende engagere sig i en restituering af verden. Den tekniske betegnelse for denne restituering er tikkun.

Fortællingernes performative funktion er at præsentere rettesnore for tikkun. På det individuelle plan er gudsfrygt og kærlighed til Gud altid blevet betragtet som den indgang, som mennesket måtte benytte, hvis det ville nærme sig Gud, fordi denne frygt og kærlighed afspejler en anerkendelse af, at Gud er universets suveræne hersker, og at hvert individ er afhængigt af Gud. Når individet har accepteret nødvendigheden af at vende om til Gud, er første performative trin, hvis man ikke skulle være jøde, selvfølgelig at konvertere til jødedommen. Ikke-jøder, der behandler jøder på retfærdig vis, vil blive belønnet af Gud. De kan imidlertid ikke aktivt bidrage til tikkun-processen, hvorfor konversion er nødvendig for ikke-jøder. Det andet trin er at erstatte menneskets tillid til menneskelig erkendelse med simpel tro. Erstatningsprocessen indebærer tilbagefald, tvivl og pinsler, som dog kan mindskes eller endda helt undgås, hvis man vælger at binde sig til en zaddik-type. Det ville repræsentere det tredie trin, der også ville inkludere zaddik-typens praktiske anvisninger i det daglige såsom anger, længsel efter forløsning, en minimal tilknytning til det dennesidige, meditationslignende fordybelse i Torah og budene, konfrontation med ondskab og opløften af de guddommelige gnister, der er indespærret bag ondskabens skaller inde i én selv. Den performative opfordring til tikkun styrkes ved at bibringe information om de belønninger, som individet kan opnå, og som kan hævdes at udgøre en forsmag på den kommende verden.

Individuel tikkun er en forudsætning for universel tikkun. Guddommelige protagonister i den universelle tikkun-proces inkluderer Gud, Shekhinah og ondskaben. De repræsenterer alle Gud og afspejler, at Gud kan tilvejebringe forløsningen, når Gud vil. Taget verdens nuværende tilstand i betragtning virker det imidlertid, som om Gud ikke vil. Forløsningen forudsætter nemlig, at alle handler i overensstemmelse med den fremlagte information om individuel tikkun. Når det sker, vil Gud motiveres til at frembringe en Zaddik haDor, der kan bane det sidste stykke vej frem mod forløsningen, hvor Gud så vil afsløre sin tofoldige natur som guddommelig transcendens og immanens.

Her er det på sin plads at spørge, hvilken rolle Nahman i så fald spiller? Når hovedparten af fortællingerne portrætterer en Zaddik haDor som den sidste 'banebryder' for forløsning, og hvis denne Zaddik haDor faktisk afspejler Nahmans selvopfattelse, forsøger Nahman med sine fortællinger at opfordre enhver tilhører/læser til at indtræde i hans samfund af hasidim for at assistere ham i tikkun-processen. Dette afspejler et selvbiografisk aspekt, hvilket imidlertid har didaktiske konsekvenser, idet Nahman i så fald ville være afhængig af, at tilhøreren/læseren reagerede på hans performative opfordring. Hvis de portrætterede Zaddikey haDor ikke afspejler Nahman, men de sidste 'banebry-

\footnotetext{
${ }^{3}$ Jeg argumenterer for, at Sippurey Ma'asiyot bør betragtes som en ny slags helligtekster, der formidler Nahmans primordiale indsigt. Shaul Magid argumenterer for, at det samme gælder Nahmans homiletiske værker, jf. Magid 2002.
} 
dende' forløsertyper, hvis komme Nahman selv håbede på, så afslører informationen om dem og opfordringen til at opsøge dem under alle omstændigheder et didaktisk formål, nemlig det at få tilhøreren/læseren til at engagere sig i individuel tikkun, der er så afgørende for den universelle tikkun.

Man kan vælge at fokusere på fortællingernes selvbiografiske aspekt, hvilket er et fuldstændig legitimt formål. Men man kan ikke benægte fortællingernes didaktiskperformative aspekt eller hævde, at det ikke skulle kunne regnes som et vigtigt element $\mathrm{i}$ fortællingerne. Fortællingerne tilbyder vejledning til enhver, der tror på, at Nahmans teologi kan hjælpe ham eller hende til at nærme sig Gud. En sådan tilhængers vej til Gud beskrives som en dialektisk proces, hvor han eller hun lytter til Nahmans oscillerende beretninger om, hvad verden er ifølge Gud, og om hvad virkeligheden er ifølge mennesket selv, indtil han eller hun overbevises om, at menneskets virkelighedsopfattelse kommer til kort. At lytte til fortællingerne og handle i overensstemmelse med den indeholdte vejledning er en forudsætning for individuel såvel som universel forløsning og for at kunne træde over tærskelen til den messianske tidsalder, hvor mennesket endelig transcenderer illusionen om en kløft mellem mennesket og Gud.

\section{Litteraturliste}

ALBINUS, LARS

2000 “Hvad er en hellig tekst?”, Hellig Tekst - Bidrag til Faglig Dag den 15. november 2000, Det Teologiske Fakultet, Århus.

BAND, ARNOLD J.

1978 Nahman of Bratslav - The Tales, New York.

1982 "The Function of the Enigmatic in Two Hasidic Tales" i Dan \& Talmage, Studies in Jewish Mysticism, Cambridge, Mass.

BEN SiMHAH, RABBi NAHMAN

1985 Sippurey Ma'asiyot, Jerusalem [1815].

BUBER, MARTIN

1906 Die Geschichten des Rabbi Nachman, Frankfurt am Main.

1923 Ich und $\mathrm{Du}$, Berlin.

DAN, JOSEPH

1975 haSippur haHasidi, Jerusalem.

GREEN, ARTHUR

1992 Tormented Master - The Life and Spiritual Quest of Rabbi Nahman of Bratslav, Woodstock [1979].

Huss, BOAZ

1998 "Sefer ha-Zohar as a Canonical, Sacred and Holy Text: Changing Perspectives of the Book of Splendor between the Thirteenth and Eighteenth Centuries", Journal of Jewish Thought and Philosophy, Vol. 7, Amsterdam.

KAPLAN, ARYEH

1983 Rabbi Nachman's Stories, Jerusalem. 
MAGID, SHAUL

2002 "Associative Midrash: Reflections on a Hermeneutical Theory in Likkutei MoHaRaN", God's Voice from the Void - Old and New Studies in Bratslav Hasidism, Albany.

NIELSEN, KIRSTEN

1989 There is Hope for a Tree - The Tree as Metaphor in Isaiah, JSOT Supplement Series 65, Sheffield.

1998 Satan - the Prodigal Son? A Family Problem in the Bible, Sheffield.

WEISS, JOSEPH

1997 "Contemplative Mysticism and 'Faith' in Hasidic Piety" [1953], "Sense and Nonsense in Defining Judaism” [1969], Studies in Eastern European Jewish Mysticism and Hasidism, London.

1974 Mehakerim beHasidut Breslav, Jerusalem.

\section{Indlæg ved Hans J. Lundager Jensen}

I det følgende indlæg taler jeg som formand for bedømmelsesudvalget og altså som repræsentant for Det Teologiske Fakultet ved Aarhus Universitet, men uden nogen speciel ekspertise i hasidismen, endsige da i Rabbi Nahman-forskningen. Mit emne vil være begrænset til nogle mere formelle anliggender og visse overordnede problemstillinger.

En afhandling som den foreliggende bør bedømmes på flere planer. For det første må man betragte afhandlingens forhold til dens præcise emne, som i dette tilfælde er Rabbi Nahmans fortællinger, og vurdere, om dens arbejde med disse tekster er overbevisende, om dette arbejde er tilstrækkeligt velfunderet i forhold til hidtidig forskning, og om den behandler denne forskning på en fyldestgørende og fair måde. For det andet må afhandlingens tese med rimelighed kunne siges at placere sig på passende vis imellem det indlysende, dvs. det trivielle, og det indlysende urimelige. En afhandlings tese eller dens hævdede resultat behøver ikke at være absolut overbevisende for alle og enhver; men den skal i besidde en tilstrækkelig grad af plausibilitet. Disse vurderinger kan i Marianne Schleichers, som i de fleste andres, tilfælde foretages, både hvad det strengt faglige angår, dvs. den snævrere og specialiserede Rabbi Nahman-forskning (som de to andre medlemmer af bedømmelsesudvalget har indsigt i), og ud fra de mere generelle problemstillinger, som jeg må holde mig til.

Først vil det måske ikke være overflødigt at understrege den akademiske karakter, de følgende bemærkninger har. Dette er ikke henvendt til Marianne Schleicher, som kender betingelserne for et forsvar af en afhandling, men til dem $\mathrm{i}$ auditoriet, som måske kan komme til at undre sig over tonen ved en anledning som denne. Det sker ikke så sjældent, at de, der ikke er specielt fortrolige med denne talegenre, kan undre sig over, hvorfor der formuleres så meget mere kritik end ros og lovprisning, og det hele så alligevel ender med, at afhandlingen erklæres for godkendt og alle er glade. Hvis den akademiske verden kan forekomme at kompensere for sit fedteri, hvad ros angår, med sin ødsle omgang med kritik, har det en elementær økonomisk årsag. Akademiet er en ta- 
lende verden, der lever af at diskutere og debattere. Det forudsætter imidlertid uenighed; hvor der kun hersker konsensus og overensstemmelse, dør den akademiske tale ud. At konstatere konsensus og enighed tager ingen tid. Uenighed, eller blot fraværet af et fælles syn på tingene, kan tage lang tid - nogle gange en evighed. Her og nu er vi i det akademiske rum.

Det bør fra begyndelsen stå fast, at når Marianne Schleicher i dag skal forsvare sin ph.d.-afhandling, er det, fordi bedømmelsesudvalget har fundet, at denne afhandling uden tvivl kan antages som ph.d.-afhandling. Den har åbenlyse og ubestridelige kvaliteter.

Først af alt: dens blotte kvantitative omfang! Afhandlingen er af imponerende størrelse for en ph.d.-afhandling: 538 sider samt alt det ekstra er usædvanligt for afhandlinger af denne type. Det er vidnesbyrd om en meget stor arbejdsindsats, gjort af en uhyre flittig person!

Dernæst: Hvad der ikke kan undgå at gøre indtryk på læseren er, at afhandlingen ikke kun demonstrerer viden om og indsigt i Rabbi Nahmans fortællinger, men også om indlevelse i dem. En person, der har skrevet så meget om disse fortællinger, må også have levet med dem, været optaget af dem, have ladet sit liv invadere af dem i et betragteligt tidsrum. Fra et strengt akademisk synspunkt er en sådan indlevelse selvfølgelig ikke i sig selv en garanti for kvaliteten af arbejdet med dem, for det akademiske arbejde fordrer naturligvis også og ikke mindst kølig distance. Alligevel finder jeg det opmuntrende, at en forsker også kan involvere sin egen person i sit emne og i den grad, som det åbenlyst er tilfældet her.

For det tredje: I alle tilfælde er den tidligere Nahman-forskning grundigt resumeret og diskuteret. Hvad der bemærkes her, er ikke kun en fair og redelig diskussion, men også den tone, med hvilken diskussionerne føres. Ikke på noget tidspunkt har læseren fornemmelsen af uberettiget arrogance eller uretfærdig forkastelse. Tonen er anerkendende, men også, når det er nødvendigt, insisterende.

For det fjerde: Som læser føler man sig tryg ved præsentationen af den komplekse og eksotiske hasidiske teologi, som ligger bag Nahmans fortællinger, og som udgør det meste af afhandlingens afsluttende kapitel. Ikke mindst dette er naturligvis et område, som de to andre medlemmer af bedømmelsesudvalget kan sige meget mere om; men som lægmand føler man sig ført ved hånden og får god besked.

Endelig, og hvad der måske er det vigtigste: Afhandlingen bør roses for relevansen og aktualiteten af dens overgribende tema. Uden tvivl er religion andet og mere end tekster. Men fra og med et vist tidspunkt $\mathrm{i}$ historien - måske navnlig i den vestlige verden, til hvilken Nahman også, trods hans ganske eksotiske verden, hører - bliver religioner på den anden side primært formidlet igennem tekster. Og dermed er spørgsmålet om, hvad en tekst er, og hvad den egentlig gør ved sin læser, afgørende. Uden tvivl ved vi en hel del allerede med al vor lingvistik, semiotik, hermeneutik, litterære teorier. Men der er fortsat meget at gøre, og afhandlingen her placerer sig selv lige i midten af en helt central diskussion. Hvad siger tekster egentlig? Hvordan gør de det? Og hvordan påvirker de, eller forsøger de at påvirke, deres læsere eller tilhørere? I for- 
hold til Rabbi Nahmans fortællinger: hvordan kan vi læse dem meningsfuldt og ansvarligt? - det vil sige: hvordan læse dem ikke blot på deres umiddelbare overflade, men også på et andet niveau eller måske på andre niveauer? Der er alle gode grunde til at antage, at Nahman ville andet og mere end at fortælle underlige historier. Enhver læser, også den helt uforberedte, fornemmer umiddelbart, at det er rimeligt at antage, at der ligger et større teologisk drama bag, eller ved siden af, de mindre dramaer i fortællingerne selv. Denne antagelse er ikke Marianne Schleichers personlige opdagelse - den er snarere konsensus i al Nahman-forskning. Men så meget mere grund er der til at antage eksistensen af en sådan 'dybde' eller en sådan 'paratekst'. Men det er også her, at der kan stilles nogle kritiske spørgsmål til afhandlingen. Dem vil jeg komme tilbage til. Først har jeg nogle andre bemærkninger.

Først og fremmest: Det er unægteligt, at arbejdets blotte størrelse demonstrerer en usædvanlig flid; men er dette ikke for meget af det gode? Akademisk arbejde består ikke kun i akkumulation, men også i selektion, og jeg kan ikke undgå at spørge mig selv, om denne afhandling ikke kunne have været betragtelig kortere? Hver enkelt af de 13 fortællinger er oversat. Det giver god mening. Men forud for hver enkelt oversættelse får læseren et grundigt resume af samme fortælling. Og som om dette ikke var tilstrækkeligt, består en ganske betragtelig del af kommentarerne til fortællingen igen af resumeer. Det sker på denne måde: Efter det første resume brydes fortællingen op i sekvenser, der oversættes; og efter oversættelsen følger kommentaren. Men et nærmere blik på kommentaren vil vise, at denne kommentar i grunden, eller for en stor dels vedkommende, er en ny sammenfatning eller genfortælling af den sekvens, der lige er blevet oversat.

For det andet må man rejse spørgsmålet om afhandlingens genre. Under læsningen blev jeg ofte i tvivl om, hvorvidt dette egentlig var en litterær studie, eller om det snarere hørte til en gren af judaistikken, en slags Jewish Studies. Men jeg vil, som givetvis mange andre, fastholde, at religionsvidenskaben er et hus med mange boliger, og at den kan huse mange beskæftigelser med undertiden kun meget løse indbyrdes forbindelser. Og eftersom afhandlingen er blevet indleveret ved Institut for Religionsvidenskab, går jeg ud fra, at den vil og bør læses i det mindste også som et bidrag til det akademiske område 'religionsvidenskab'.

Men jeg ville gerne høre Marianne Schleichers mening om, på hvilken måde den gør det eller, for at formulere spørgsmålet lidt mere præcist, i hvilken region af religionsvidenskaben, den hører hjemme. Normalt vil en god, skønt selvfølgelig i første omgang rent udvendig og overfladisk, indikation af svaret på et sådant spørgsmål være referencer til aktuelle debatter, brug af et alment anerkendt vokabular eller visse centrale metodiske begreber, for ikke at nævne citater fra og diskussioner med førende forskere inden for det pågældende akademiske område. Men i denne afhandling er sådanne referencer og henvisninger næsten totalt fraværende. Bibliografien har 118 titler. Blandt dem er der meget få, der ligger uden for Nahman-, hasidisme- og generel judaistisk forskning. Og blandt de øvrige er der ikke en eneste virkelig 'klassiker' fra religionsvidenskaben i bredeste forstand. Det samme kan siges om brugen af centrale begreber, ja, endog om 
afhandlingens centrale tema. Der er faktisk, det skal indrømmes, en kort reference til Victor Turner og det liminale rum (s. 21); men helt bortset fra, at netop denne reference tangerer det trivielle, har den så ringe betydning for afhandlingen som helhed, at den ingen forskel gør, hvilket vel også er grunden til, at Turner heller ikke har fundet vej til afhandlingens bibliografi. Så altså: Hvorfor involverer afhandlingen sig ikke i højere grad med centrale religionsvidenskabelige problemstillinger? Var det simpelthen det tidskrævende arbejde med fortællingerne selv, som ikke gav tid til og mulighed for at engagere sig bredere?

$\mathrm{Nu}$ er afhandlingens titel A Theology of Redemption. Det fik mig til at overveje, om ikke afhandlingens genre i grunden er 'teologi'? Ordet 'teologi' kan anvendes i en deskriptiv betydning, som når man taler om en bestemt persons 'teologi', om en særlig form for egyptisk eller babylonsk teologi, om forskellige teologier i Det Gamle Testamente osv. Så er afhandlingen i sig selv i grunden en "teologi" i denne betydning af ordet, en særlig form for jødisk teologi, altså et forsøg på at beskrive Nahmans teologi, og naturligvis primært i den form, den foreligger i fortællingerne, for læseren? Dette forudsætter vel, at deskriptiv teologi er en nødvendig del af enhver form for religionsvidenskab. Selveste Durkheim mente noget lignende, da han i sin Formes élémentaires de la vie religieuse understregede, at uden kendskab til, hvad en religion faktisk siger og hvad dets medlemmer faktisk tror, giver religionsvidenskab ikke megen mening. Kan vi derfor konkludere, at denne afhandling hører hjemme i religionsvidenskaben, fordi den tilbyder en introduktion til en bestemt teologi, som kunne analyseres mere dybtgående og på en teoretisk mere ambitiøs måde ved hjælp af andre komponenter i religionsvidenskaben? Men undertiden kan introduktionen udgøre den bedste del. Og sådan er det måske også her, fordi teologien selv er så interessant, så fascinerende, at det forekommer mere givtigt at gå dybere ned i den end at begynde med at 'forklare' den i forhold til ydre faktorer, fra historiske, sociologiske, psykologiske eller andre perspektiver og dertil hørende teorier og metoder?

Udover således - formodentlig - at være en teologi er afhandlingen selvfølgelig først og fremmest en "analysis of the thirteen tales in Rabbi Nahman of Bratslav's Sippurey Ma'asiyot”, som undertitlen gør klart. Og dette bringer mig tilbage til et punkt, jeg var ved at gå ind på tidligere, nemlig spørgsmålet om selve læsningerne af fortællingerne.

For det første er den teoretiske fundering en anelse mere eksplicit, end man kan sige om afhandlingens generelle karakter som bidrag til religionsvidenskaben. Afhandlingen har et dobbelt formål: den vil undersøge fortællingerne både "as an instance of the use of imagery" og "as "canonical and sacred texts"” (s. 4). Hvad det første punkt, billedsproget, angår, har afhandlingen et teoretisk fundament, om end ikke meget bredt: Bibliografien anfører titler af Kirsten Nielsen og Paul Ricoeur og, måske i den mere trendy afdeling, Harold Bloom og Susan Handelman. Men hvor vigtige er disse forfattere og deres ideer for de aktuelle analyser? Harold Bloom og Susan Handelman spiller ingen prominent rolle, og det eneste sted, de nævnes, så vidt jeg har opfanget, er i en fodnote til side 56 og her kun som inspiration for en anden forsker (Shaul Magid), som ser ud til 
at være langt nærmere afhandlingens egentlige interesser. Når det kommer til det andet punkt, spørgsmålet om 'kanoniske og hellige tekster', er det teoretiske grundlag så snævert, at det tenderer det ikke-eksisterende; for alt, hvad der anføres, er et internt papir af vor kollega Lars Albinus og en artikel af Boaz Huss. For nu at sige det lige ud: dette er meget lidt; ville det have været nok for et hovedfagsspeciale? Man får et indtryk af, at Marianne Schleicher har forsøgt at afbalancere det, det vel egentlig kommer an på i afhandlingen, dens egentlige emne - Nahmans fortællinger og analyserne af dem - med noget mere 'teoretisk', noget af en bredere relevans, men at resultatet på dette punkt ikke er vellykket; det efterlader en asymmetri mellem teori og empiri, mellem generelt og specielt, der ikke er til at tildække.

Men altså: Marianne Schleicher har grundlæggende valgt sig billedsprogstilgangen som sit apparat til Nahmans fortællinger. Disse fortællinger er uden tvivl 'litterære' i den elementære betydning, at de er blevet til af en navngiven forfatter i et nærmere defineret tidsrum. Men i disse fortællinger er der unægtelig også megen 'folklore', hvad der også står tidligere Nahman-forskning klart. I fortællingerne finder vi en mængde folkeeventyrskarakterer og eventyrmotiver, konger og fattigfolk, unge helte og bortførte prinsesser, forbyttede børn, fortryllede skove og gyldne bjerge, perleslotte og huse flyvende i luften. Jeg er klar over, at det er den billigst tænkelige kritik at spørge efter, hvorfor en forsker har undladt at beskæftige sig med et emne, når han eller hun nu engang har valgt at beskæftige sig med noget andet. Når jeg alligevel kommer ind på det her, er det, fordi Nahmans fortællinger for mig at se ikke blot generelt ligger eventyrgenren nær, men at der her er tale om en variant, der også ligger ganske nær den eventyrverden, der har spillet en helt central rolle for moderne, semiotisk narratologi, nemlig det russiske trylleeventyr, som det blev analyseret i Vladimir Propps bog om folkeeventyrets morfologi. Det forekommer mig at måtte ligge snublende nær ikke kun at nævne dette slægtskab med en narratologisk klassiker, men også at inddrage slægtskabet produktivt. For det er vel ikke utænkeligt, at ved at have fulgt narratologien fra Propp til Greimas, fra overflade- til dybdestrukturer, var det blevet mere indlysende, hvorfor Nahman kunne artikulere sin hasidiske teologi i et folkeeventyrsunivers. Forklaringen ligger i så fald snublende nær: fordi denne teologi selv er struktureret som et eventyr, selv forudsætter elementære, narrative strukturer og, som man måske vil tilføje i dag, af sin tilhører eller læser forudsætter elementære narrative kompetencer. I så fald ville det ikke være teologien, der var nøglen til eventyrerne, men omvendt. Det ville også være at vende Marianne Schleichers afhandling på hovedet; men forestillingen om en eventyrlig teologi ville måske ikke være hende helt fremmed?

Mit sidste punkt i denne kritiske afdeling er også det vigtigste. På trods af den erklærede optagethed af billeder og helligtekster osv. forekommer det mig, når alt kommer til alt, at analyserne af fortællingerne $i$ afhandlingen $i$ grunden er rent allegoriske. Det fremgår klart nok, at afhandlingen snarere tilslutter sig de forskere, der betragter fortællingerne som teologiske belæringer, end dem, der vil se dem som udtryk for Rabbi Nahmans turbulente ydre og indre liv. Det må eksperterne selvfølgelig afgøre, selv om synspunktet unægtelig forekommer plausibelt. Men jeg har derimod vanskeligheder 
med hovedtesen, der angår, hvad disse fortællinger egentlig er. Det hedder lige fra begyndelsen, at "the success of a figurative expression will be achieved, when it is uttered without an existing consensus or a following fixation of the interpretation, because in such cases it invites the listener or the reader to participate in the interpretive act of deriving information from the figurative expression" (s. 2f; jeg kursiverer). Dette punkt er så vigtigt for afhandlingen som helhed, at det genfremsættes i det afsluttende kapitel (s. 536): det ligger i billedsprogets og intertekstualitetens natur at indbyde tilhøreren eller læseren til at deltage i fortolkningen ("invite the listener/reader to engage in the interpretative act"). Det tilføjes her, at de analyser, der har været bragt - og som udgør den allerstørste del af afhandlingen - også afspejler ('reflect') denne fortolkningsaktivitet. Det bliver ligeledes understreget (s. 536f), at disse analyser ikke gør krav på fuldstændighed, og at de ikke udelukker, at andre - her gælder det vel at mærke andre lærde ("scholars") - kan tænkes at uddrage andre særtræk ved fortællingerne. Det eneste, afhandlingen ønsker at vise, er, at de her bragte fortolkninger har vist, at "it is possible to read Nahman's tales as replete with imagery and intertextuality and accordingly to derive information" (s. 537: jeg kursiverer). Dette lyder tilforladeligt nok, om end måske en anelse for vagt - for der var vel fra starten ingen tvivl om, at det var muligt at læse Nahmans fortællinger på denne måde; spørgsmålet er jo, hvorvidt denne læsestrategi er relevant og vigtig?

Men på trods af den ikke-insisterende stil her udvikler analyserne af fortællingerne sig ikke desto mindre ofte til autoritative udlægninger, hvor elementerne a og b i en given fortælling betegner $\mathrm{x}$ og y $\mathrm{i}$ den teologi, der er fortællingernes fælles baggrund. Man kan fx tage konklusionen på fortolkningen af den tolvte fortælling, "The Master of Prayer" (s. 454). Her fremhæves det, at hovedpersonen i fortællingen, bønnens herre, bør fortolkes ('should be interpreted') som Zaddik haDor, den der udløser den messianske tid; kongen repræsenterer det mest transcendentale aspekt ved Gud, datteren repræsenterer Shekinah, hendes søn repræsenterer den davidiske Messias. Det er (for mig at se, den uinformerede læser) meget muligt, at dette er en plausibel analyse; men i så fald er det ikke just en "invitation" uden "a following fixation". Analysen her forekommer mig at se ud som enhver anden autoritativ, allegorisk afkodning, hvor en bønsherre er dette, en konge er hint, en prinsesse er noget tredje. Og ligger dette ikke i den allegoriske læsnings natur: at den så langt fra at åbne teksten snarere vil lukke den? I hvert fald synes fortolkningens retorik her at pege i den retning: a er $\mathrm{x}, \mathrm{b}$ er $\mathrm{y}$.

Der er dog også en anden tone i den allegoriske afkodning, som muligvis er den mere dominerende, når alt kommer til alt. I den samme passage er der et problem med afkodningen af dronningen i fortællingen: "the queen could represent divine understanding”. Der er mange eksempler på en sådan tøven i afhandlingen. Man kan fx tage s. 385 (om den elvte fortælling, "The King's Son and the Maid's Son Who Were Switched"). Her 'synes det' ("it seems"), som om kongens virkelige søn repræsenterer sjælen, at jordemoderen 'kan fortolkes' ("can be interpreted") som Lilit; her 'formoder' Marianne Schleicher ("I think"), at det mest sandsynlige er ("it is more likely"), at stolen repræsenterer Messias etc. 
Hvad der foregår her er imidlertid, formoder jeg, ikke en fejring af de mange muligheder og vore frie valg på de litterære fortolkningers marked; men snarere, en allegorisk læsning, der endnu er på jagt efter den rette afkodning. Måske er jordemoderen i fortællingen Lilit, og måske er hun ikke - hvem ved? Det er selvfølgelig meget vigtigt at vide, hvis man antager, at der gives en korrekt afkodning. Men hvis der ikke gives en sådan korrekt afkodning, er så hele det allegoriske projekt ikke tomt? Og så på den anden side: hvis der faktisk er en korrekt afkodning, ifølge hvilken jordemoderen er Lilit, er det da ikke vanskeligt alvorligt at tale om indbydelse til deltagelse i noget, eftersom de smukke ord i så fald egentlig betyder, at læseren bør underkaste sig den sande mening, ifølge hvilken jordemoderen er Lilit?

Men hvis det er sådan, det egentlig er, så melder et velkendt spørgsmål endnu engang sin ankomst: for hvis der er en sand mening, en teologi under eller bag ved de tilsyneladende så uskyldige og læser-åbne fortællinger, hvorfor så ikke lade sig nøje med teologien selv, ordret og ligefrem?

Det er selvfølgelig just det spørgsmål, som Marianne Schleichers afhandling begynder med; men den slutter også med det. Afhandlingen vil være allegoriserende, og dog ikke; den vil både have den sande mening og ikke have den, både fortælle folk, hvad der er meningen med Nahmans fortællinger, og overlade til dem selv at finde ud af, hvad de evt. kan betyde for dem, både invitere alle indenfor og indskrænke invitationen til dem, der kan have en kvalificeret mening, de andre scholars. Hvis min intuition er rigtig, så ville Marianne Schleicher, hvis hun hårdt presset blev afæsket en stillingtagen, formentlig vælge at spise kagen snarere end at beholde den; jeg tror, at hun egentlig helst ville sige, at teksten ikke er åben, at den ikke kan læses på alle mulige, private måder, men tværtimod insistere på (under tilbørlig frygt og bæven), at der er en rigtig læsning, den rigtige læsning, hendes rigtige læsning - som er, at bønnens herre er Zaddik haDor, kongen er Gud, datteren er Shekinah. En sådan læsning er naturligvis 'autoritativ’ og, om man vil, 'autoritær'; men det er også den eneste læsning, hvor viden og indsigt egentlig betyder noget, hvor det faktisk gør en forskel, om man kan læse fortællingerne på hebraisk og jiddisch eller ej, om man har gjort sit hjemmearbejde, hvad angår Rabbi Nahmans sociale, historiske, teologiske og biografiske kontekst. Men Marianne Schleicher har gjort sit hjemmearbejde, og derfor falder det hende svært at afholde sig fra at insistere på, at hendes læsninger er de rette, og at nogle læsninger derfor er bedre end andre, og at læsninger lukker snarere end åbner. Og sådan bør det vel også være i en akademisk kontekst, som ikke er total åben, hvor det ikke er sådan, at alle ved lige meget, og hvor det ikke er alle, som erhverver en ph.d.-grad i Religionsvidenskab eller som med rette kan kalde sig Rabbi-Nahman-forsker?

Men noget holder tydeligvis Marianne Schleicher tilbage - ikke kun en i og for sig plausibel teori om, at fiktionstekster er åbne tekster, og ikke kun en aldeles rimelig undseelighed ved at udelukke i det mindste forskerkolleger fra det plausibles felt, men også, måske, en frygt, som vel må hjemsøge alle, som bedriver allegori: hvad nu, hvis jeg tager fejl? Hvad nu, hvis kongen alligevel ikke 'er' Messias og datteren alligevel ikke 'er' Shekinah? Men hvis dette er den stiltiende konklusion på Marianne Schlei- 
chers afhandling, så er det endnu en grund til at anbefale den som et stykke akademisk arbejde, for dette er al akademisk arbejdes skæbne: Hvad hvis jeg tager fejl? hvad hvis det alligevel ikke hænger sammen på den måde, som jeg troede?

Til indledning sagde jeg, og jeg gentager det her, at det hører med til det akademiske sprogspil, at vi går let hen over enighed og konsensus og koncentrerer os om uenighed og stridspunkter. Marianne Schleichers arbejde får læseren til at overveje, stille spørgsmål, også sige imod. Men på trods af alle indvendinger er konklusionen, at hendes afhandling er solid og god, når det kommer til det afgørende: Rabbi Nahmans fortællinger og deres kulturelle, historiske og teologiske kontekst. Afhandlingen diskuterer sit egentlige anliggende i en god, solid og sober akademisk form; den tilhører en af religionsforskningens mange kamre. Den bør fortjene sin forfatter ph.d.-graden. 